\title{
The upper Maastrichtian dinosaur fossil record from the southern Pyrenees and its contribution to the topic of the Cretaceous-Palaeogene mass extinction event
}

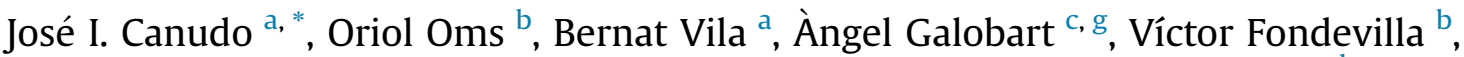 \\ Eduardo Puértolas-Pascual a ${ }^{\mathrm{a}}$, Albert G. Sellés ${ }^{\mathrm{c}}$, Penélope Cruzado-Caballero ${ }^{\mathrm{d}}$, \\ Jaume Dinarès-Turell ${ }^{\mathrm{e}}$, Enric Vicens ${ }^{\mathrm{b}}$, Diego Castanera ${ }^{\mathrm{a}}$, Julio Company ${ }^{\mathrm{f}}$, Laura Burrel ${ }^{\mathrm{b}}$, \\ Rita Estrada ${ }^{\mathrm{b}}$, Josep Marmi ${ }^{\mathrm{c}}$, Alejandro Blanco ${ }^{\mathrm{c}}$ \\ a Aragosaurus-IUCA, Paleontología, Facultad de Ciencias, Universidad de Zaragoza, 50009, Zaragoza, Spain \\ ${ }^{\mathrm{b}}$ Universitat Autònoma de Barcelona, Facultat de Ciències (Geologia), 08193, Bellaterra, Barcelona, Spain \\ ${ }^{\mathrm{C}}$ Institut Català de Paleontologia Miquel Crusafont, C/ Escola Industrial 23, 08201, Sabadell, Spain \\ d CONICET, Instituto de Investigación en Paleobiología y Geología, Universidad Nacional de Río Negro, Av. Roca 1242, General Roca, 8332, Río Negro, \\ Argentina \\ e Istituto Nazionale di Geofisica e Vulcanologia, Via di Vigna Murata 605, 00143, Roma, Italy \\ ${ }^{\mathrm{f}}$ Departamento de Ingeniería del Terreno, Universidad Politécnica de Valencia, Camino de Vera s/n, 46022, Valencia, Spain \\ ${ }^{g}$ Museu de la Conca Dellà, C/ del Museu 4, 25650, Isona i Conca Dellà, Lleida, Spain
}

\section{A R T I C L E I N F O}

\section{Article history:}

Received 3 June 2015

Received in revised form

23 June 2015

Accepted in revised form 23 June 2015

Available online 9 July 2015

\section{Keywords:}

$\mathrm{K}-\mathrm{Pg}$ extinction

Dinosaurs

Pyrenees

Tremp Formation

\begin{abstract}
A B S T R A C T
In the present paper, the fossil record of the archosaurs (dinosaurs, crocodylomorphs and pterosaurs) of the southern Pyrenees before the Cretaceous-Palaeogene $(\mathrm{K}-\mathrm{Pg})$ transition is revised. On the basis of this fossil record, a well-dated succession of dinosaurs and other archosaurs is established within polarity magnetochrons C30 and C29r. Almost 150 sites with dinosaur remains have been identified, containing hadrosauroid ornithopods, titanosaur sauropods and theropods, as well as egg sites and tracks. Fossil remains of dinosaurs and other archosaurs are abundant in C29r, disappearing abruptly near the top of the "Lower Red Garumnian" unit of the Tremp Formation. Thus this should be located very close to, or coinciding with the $\mathrm{K}-\mathrm{Pg}$ boundary. These data suggest that the disappearance of the dinosaurs and other archosaurs was geologically abrupt in the southern Pyrenees, but to date there is no incontrovertible evidence of the presence of the impact level that marks the Cretaceous-Palaeogene boundary. Interestingly, what is highlighted in the southern Pyrenees is that the vertebrate-rich upper Maastrichtian continental sites were replaced by similar sedimentological facies characterized by the virtual absence not only of dinosaurs but also of any vertebrate remain throughout the lower Palaeocene. This could mean that the Danian terrestrial ecosystems of the southern Pyrenees took longer than other areas of the world to recover their biodiversity after the $\mathrm{K}-\mathrm{Pg}$ extinction event.
\end{abstract}

(๑) 2015 Elsevier Ltd. All rights reserved.

\section{Introduction}

At the end of the Cretaceous the Earth underwent a major set of dramatic events. These include changes in global and regional climatic patterns (Li \& Keller, 1998), marine regressions (Miller et al., 2005) and a huge asteroid striking the Earth (Alvarez, Alvarez,

\footnotetext{
* Corresponding author.

E-mail address: jicanudo@unizar.es (J.I. Canudo).
}

Asaro, \& Michel, 1980; Smit \& Hertogen, 1980). In addition, fissures on the Indian continent spewed forth thousands of cubic kilometres of volcanic material (Courtillot et al., 1988; Tobin et al., 2012). All these events have been suggested to be the cause of the Cretaceous-Palaeogene $(\mathrm{K}-\mathrm{Pg})$ mass extinction although there is a general consensus that it most probably derived from environmental consequences of the extraterrestrial impact that occurred 66 Ma (Renne et al., 2013; Schulte et al., 2010). Researchers analyse the patterns of extinction and survival in the biota and measure the effects of such events on the faunas living at 
the time by examining the fossil record to find out which organisms survived the $\mathrm{K}-\mathrm{Pg}$ mass extinction event and which did not (Archibald \& Fastovsky, 2004; Brusatte et al., 2015; Canudo, 1997; MacLeod et al., 1997; Molina et al., 2006). A good example is the sudden extinction of typical late Maastrichtian planktonic foraminifera coinciding with evidence of an extraterrestrial impact, a hypothesis proposed by Alvarez et al. (1980) and Smit and Hertogen (1980) on the basis of studies of planktonic foraminiferal successions and other evidence in sections from Gubbio (Italy) and Caravaca (Spain), respectively. At present, the connection between these two events is accepted (Schulte et al., 2010), notwithstanding the possibility that there may have been other factors that contributed to the extinction. Since the proposal of the meteorite hypothesis, vertebrate palaeontologists have been searching for evidence of the relationship between the extinction of the dinosaurs and the meteorite impact (Brusatte et al., 2015). The extinction of the majority of dinosaurs (except Aves) within a relatively small period of time is well documented in quite a few regions of the planet; moreover, the impact of a large extraterrestrial object 66 million years ago has been sufficiently substantiated on the Yucatán Peninsula in Mexico (Schulte et al., 2010). There has been a long debate about the events that contributed to the decline of dinosaurs, and to what extent these events may have been responsible for their extinction (Archibald et al., 2010; Brusatte et al., 2015; Fastovsky \& Sheehan, 2005). More importantly, scientists still debate whether the extinction was geologically gradual or abrupt (instantaneous) and how this is linked with the perturbations propounded by the impact hypothesis.

Geological instantaneousness is a very inexact amount of time, particularly in continental environments, where hiatuses are the rule rather than the exception. Vertebrate palaeontologists cannot resolve time spans of less than tens of thousands of years at a temporal distance of 66 million years. The same palaeontological record can be preserved regardless of whether the extinction took a minute or many thousands of years. In 10,000 years, a whole class of gradual processes and extinctions may occur, represented by a geologically instantaneous extinction. This pattern is fundamental to the question of ascertaining whether the extinction was an instantaneous catastrophe or rather a phenomenon that spread gradually over time. Non-avian dinosaurs disappeared from the fossil record in all the continents at the end of the Cretaceous, at the boundary with the Palaeogene. This disappearance is a global phenomenon and "so dramatic that the absence of dinosaur fossils was often considered sufficient to assign a Cenozoic age to strata above dinosaur-bearing rocks" (Brusatte et al., 2015). Nonetheless, there are few places in the world that have a good record of the last dinosaurs, i.e. a record containing rocks of a late Maastrichtian age, the geological age that lasted from 69 to 66 million years ago. Documenting the global extinction of the dinosaurs will clearly require us to have a dinosaur record for the Late Cretaceous in many areas around the world (Archibald \& Fastovsky, 2004; Le Loeuff, 2012); that is, it will call for a search for stratigraphically complete fossil records around and containing the $\mathrm{K}-\mathrm{Pg}$ boundary. The western interior of North America is the area where the biodiversity of the last dinosaurs is best known, even though this is not without controversy (Brusatte et al., 2015; Fassett, Zielinski, \& Budahn, 2002; Fastovsky \& Sheehan, 2005). The Hell Creek Formation in North America is one of the few places in the world where there is a continuous sequence in continental facies between the Cretaceous and Palaeogene. The iridium peak that marks the Cretaceous-Palaeogene boundary has also been found at the top of this formation (Clemens \& Hartman, 2014).

The second-best region for studying the evolution and extinction of latest Cretaceous dinosaurs is southwestern Europe. In particular, the southern Pyrenees region (Spain) provides an expanded continental record of the uppermost Cretaceous and lowermost Palaeogene (López-Martínez, Ardèvol, Arribas, Civis, \& González-Delgado, 1998; Oms et al., 2007; Riera, Oms, Gaete, \& Galobart, 2009). For the last 15 years, intensive research in the area by the research teams involved in studying the extinction of latest Cretaceous dinosaurs in the Pyrenees has considerably improved what is known of vertebrate biodiversity (including dinosaurs) and the associated environmental and chronological framework. Such studies include the systematics and biodiversity of tetrapods and their biodiversity just before the $\mathrm{K}-\mathrm{Pg}$ boundary (Blanco, Bolet, Blain, Fondevilla, \& Marmi, 2015; Blanco, Méndez, Marmi, 2015; Dalla Vecchia et al., 2013; López-Martínez et al., 2001; Cruzado-Caballero, Pereda-Suberbiola, \& Ruiz-Omeñaca, 2010; Cruzado-Caballero, Ruiz-Omeñaca, Canudo, 2010; PeredaSuberbiola, Canudo, Company, Cruzado-Caballero, \& Ruiz-Omeñaca, 2009; Pereda Suberbiola, Canudo, Cruzado-Caballero, et al., 2009; Prieto-Márquez, Dalla Vecchia, Gaete, \& Galobart, 2013; Riera et al., 2009; Torices, Currie, Canudo, \& Pereda Suberbiola, 2015; Vila et al., 2013), the study of hundreds of dinosaur eggshells and clutches (Sellés, Vila, \& Galobart, 2014a; Vila, Galobart, Oms, Poza, \& Bravo, 2010, Vila, Jackson, Fortuny, Sellés, Galobart, 2010; 2011), and of dinosaur and crocodile footprints (Vila et al., 2013, 2015). In addition to our interest in the continuity of the facies and vertebrate successions across the $\mathrm{K}-\mathrm{Pg}$ boundary, the position of the Iberian Peninsula is of particular palaeobiogeographical relevance. At the end of the Cretaceous, what is now Europe was an archipelago (Dercourt, Gaetani, Vrielvynck, Barrier, \& Biju, 2000), with the area known as the Ibero-Armorican domain (comprising what is now Provence, the Pyrenees and the northern and southern Iberian Ranges) as the largest island in the European archipelago (Philip \& Floquet, 2000). Moreover, the Iberian Peninsula was situated in the vicinity of the Tethys region, where the effects of the impact may have been especially marked. Indeed, in the marine environments of the Pyrenees one finds some of the classic sites in investigations into the Cretaceous-Palaeogene boundary (Molina, Arenillas, \& Arz, 1998; Smit \& Hertogen, 1980).

Accordingly, the main goal of this paper is to provide an overview of the record of the last dinosaurs and other archosaurs at the upper Maastrichtian localities of the southern Pyrenees and to discuss this record in the light of the $\mathrm{K}-\mathrm{Pg}$ extinction event. New significant data from the Campo reference section are also provided.

\section{Geographical and geological context}

The study area is located in the Pyrenees of northern Catalonia and Aragón (NE Iberian Peninsula; Fig. 1). The Pyrenees is an eastwest-oriented mountain chain with a basement roughly coincident with the France-Spain border. The Pyrenees resulted from the collision between the micro-continental Iberian Plate and the southwestern promontory of the European Plate during the Alpine orogeny that took place from the late Campanian to Eocene (Muñoz, 1989; Puigdefàbregas et al., 1986; Teixell, 2004). The thick outcrops of the South-Pyrenean Zone of Maastrichtian and Palaeocene age are known as the Tremp Formation. Mey, Nagtegaal, Roberti, and Hartelvelt (1968) defined this formation, and later it was ranked as the Tremp Group, which was divided into several formations on the basis of internal stratigraphic differences (Cuevas, 1992; Pujalte \& Schmitz, 2005). However, here we use "Tremp Formation" due to the absence of significant stratigraphical discontinuities in this lithologic unit. The Tremp Formation is also referred to as the "Garumnian" facies. This unit accounts for the terrestrial and lagoonal sediments deposited at the end of the Cretaceous and the beginning of the Palaeogene (see historical review in Rosell, Linares, \& Llompart, 2001). The Tremp Formation is 


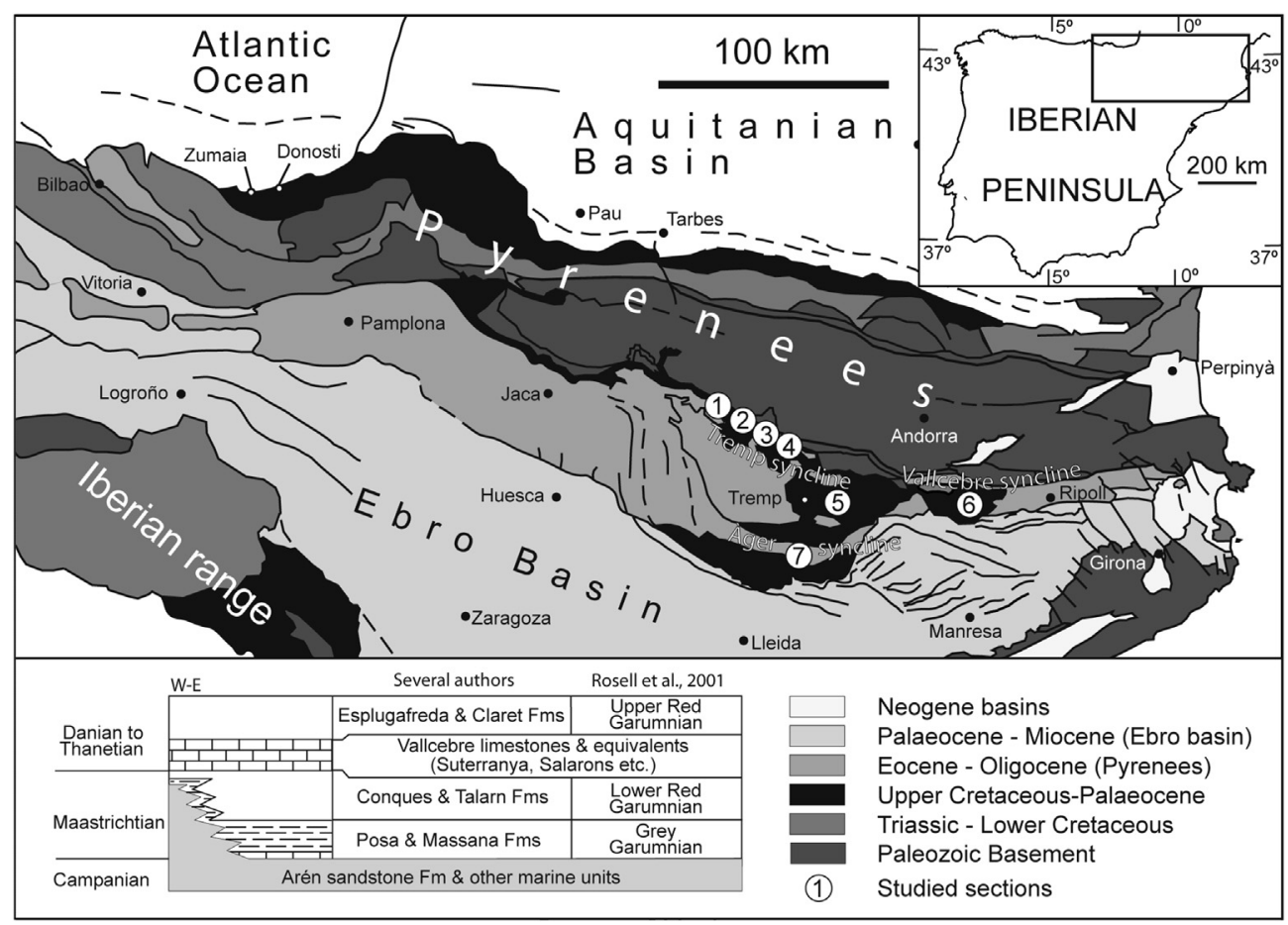

Fig. 1. Top: geological map of the Pyrenean area with the location of the studied sections. Bottom: schematic stratigraphy of the Tremp Group or "Garumnian".

exposed over some $100 \mathrm{~km}$, from the province of Barcelona (Catalonia) to Huesca (Aragón). The maximum thickness is $800 \mathrm{~m}$, but this decreases significantly in some parts of the basin, particularly in the southern (passive) margin and in the western areas. It comprises multiple sections distributed in various geographical areas of the southern Pyrenees (Fig. 1). There are four areas with significant dinosaur remains: the Vallcebre Syncline, the Coll de Nargó area, the Tremp Syncline and the Àger Syncline.

The Tremp Formation in the eponymous syncline and basin overlies and is laterally equivalent to the upper Campanian-Maastrichtian of the Arén Sandstone Formation. The boundary between these formations is largely diachronous because these units were deposited during a regressive event in which the sea was retreating to the west (i.e. towards the Atlantic). The Tremp Formation can be subdivided into four informal lithological units named as follows from the base to the top: the "Grey Garumnian", the "Lower Red Garumnian" (here abbreviated to the LRG unit), the Vallcebre Limestone (and lateral equivalents) and the "Upper Red Garumnian" (Rosell et al., 2001).

The "Grey Garumnian" is also known as the Posa Formation in the Tremp and Vallcebre synclines and is mainly built up of greyish marl with intercalations of coal and sandstone. It is interpreted as lagoonal or estuarine deposits (Oms et al., 2015; Rosell et al., 2001; Villalba-Breva \& Martín-Closas, 2012), and it contains fossil remains of marine and lagoonal organisms such as foraminifera, molluscs, rudists, corals and chondrichthyan fishes, as well as freshwater organisms such as ostracods and charophytes, vascular plants and continental vertebrates such as dinosaurs, crocodylomorphs, chelonians, lizards and lissamphibians (Blain, Canudo, Cuenca-Bescós, \& López-Martínez, 2010; Blanco, Puértolas-Pascual, Marmi, Vila, \& Sellés, 2014; López-Martínez et al., 2001; Pereda Suberbiola, Canudo, Company, et al., 2009; Pereda Suberbiola, Canudo, Cruzado-Caballero, et al., 2009; Villalba-Breva, Martín-Closas, Marmi, Gomez, \& FernándezMarrón, 2012, 2015). In the Àger Syncline, the unit is also known as the Maçana Formation, and is represented by lacustrine limestones
(Villalba-Breva \& Martín-Closas, 2012).

The LRG unit (or Conques and Talarn Formation) is a succession of bioturbated mudstones and sandstones suggesting deposition in a fluvial setting that was influenced by tides (Díez-Canseco, Arz, Benito, Díaz-Molina, \& Arenillas, 2014). The LRG unit has fossil remains of marine organisms such as planktonic foraminifera deposited after being transported landwards from the outer/inner shelf, as well as freshwater organisms such as ostracods and charophytes. Continental vertebrates include lizards, lissamphibians, dinosaurs, crocodylomorphs, chelonians and pterosaurs (Blanco, Bolet, et al., 2015; Casanovas, Santafé, Sanz, \& Buscalioni, 1987; Dalla Vecchia et al., 2014; Díez-Canseco et al., 2014; Marmi et al., 2012; Puértolas-Pascual, Canudo, \& Moreno-Azanza, 2014; Vila et al., 2012). Fossils of vascular plants are also present in the LRG (Marmi et al., 2015). A conspicuous sandstone and/or conglomerate level (Reptile Sandstone) occurs near the top of the LRG unit in the Àger and Vallcebre synclines (Blanco, Méndez, et al., 2015; GómezGras et al., 2015; Llompart, 1979; López-Martínez et al., 1998), separated from the overlying Vallcebre limestone by a few metres of mudstone (Masriera \& Ullastre, 1983).

The Suterranya Limestone overlies the LRG unit. These lacustrine and palustrine limestones and marls, which contain abundant charophytes, molluscs, ostracods and foraminifera, are lateral equivalents of the Vallcebre Limestone. This unit has been interpreted as deposited in fluvial plains and brackish-freshwater coastal lakes or ponds (Díez-Canseco et al., 2014; López-Martínez, Arribas, Robador, Vicens, \& Ardèvol, 2006).

\section{Sections with a cretaceous-palaeogene transition in the continental southern Pyrenees}

The marine sections of the Pyrenees such as Zumaya in the Basque Country (Spain) and Bidart (France) are classical in the study of the K-Pg boundary (Arz, Arenillas, \& Molina, 1999; Gallala, Zaghbib-Turki, Arenillas, Arz, \& Molina, 2009) and have been the subject of integrated stratigraphic studies and orbital tuning along 
the Maastrichtian and Paleocene strata (Dinarès-Turell, Westerhold, Pujalte, Röhl, \& Kroon, 2014, and references therein). The situation is very different in the case of continental or transitional deposits, where there are no planktonic foraminifera and the only criteria for identifying the boundary are features such as the iridium-bearing stratum layer, microtektites or other exotic materials derived from the meteorite impact.

Since the 1980s (Feist \& Colombo, 1983; Médus et al., 1988) and especially in the last few years, a great effort has been made to pinpoint the boundary within the Cretaceous and Palaeogene continental deposits of the southern Pyrenees (Colombo, 1996; Díez-Canseco et al., 2014; Fernández-Marrón, López-Martínez, Fonollá-Ocete, \& Valle-Hernández, 2004; López-Martínez et al., 1998; Oms et al., 2007, 2014; Riera et al., 2009, 2013). However, the boundary has never been identified by means of direct evidence such as an iridium-bearing stratum, a fern spike or microtektites, leading some authors to suggest that the $\mathrm{K}-\mathrm{Pg}$ transition may be lost within a hiatus (Baceta, Pujalte, Serra-Kiel, Robador, \& OrueEtxebarria, 2004; Díez-Canseco et al., 2014). Yet apart from small local hiatuses typical of continental environments, the majority of authors who have studied the geology of the Tremp Formation have found no evidence of significant hiatuses (López-Martínez, Fernández-Marrón, \& Valle, 1999; Oms et al., 2007; Riera et al., 2009).

In attempting to locate the transition between the Cretaceous and the Palaeogene, other, more indirect evidence has been used, with varying degrees of success. For example, the abundance of Microcodium has been used as a biomarker of the Palaeogene, but this also appears in the Maastrichtian of the Tremp Formation, so it is not a reliable criterion for identifying the boundary (Díaz-Molina, Kalin, Benito, López-Martínez, \& Vicens, 2007). The palynological data published to date do not support a floral turnover across the $\mathrm{K}-\mathrm{Pg}$ boundary in the southern Pyrenees (Fernández-Marrón et al., 2004; López-Martínez et al., 1999). Even though no impact layer has yet been found in the continental Pyrenean sections, progress is being made by means of magnetostratigraphy, isotopic studies, stratigraphic correlations with marine series, as well as biostratigraphically important fossils such as charophytes, palynomorphs, foraminifera, rudists and dinosaur oospecies in the upper part of the LRG unit or just below the contact between this unit and the Campo, Suterranya and Vallcebre limestone units.

Here, we describe the geological and palaeontological record of the main continental sections (Campo, Serraduy-Rin, Iscles, Blasi, Isona, Fontllonga and Vallcebre) that encompass a $\mathrm{K}-\mathrm{Pg}$ transition in the southern Pyrenees (Fig. 2). The location or the absence of the $\mathrm{K}-\mathrm{Pg}$ boundary in this area within them is also discussed.

\subsection{Campo section}

This section contains a thick Upper Cretaceous and Palaeogene record (Fig. 2 and Suppl. Fig. 1 and 2). It has been studied for what it reveals of the Cretaceous, Palaeocene and Eocene stages of the southern Pyrenees and is of special importance at the PalaeoceneEocene boundary because in this section the parastratotype of the Ilerdian stage was defined (Molina et al., 2003; Payros et al., 2000). The Maastrichtian part of the section is more than $1000 \mathrm{~m}$ thick (see Supplementary information, Fig. 1), but the upper $30 \mathrm{~m}$ (labelled "detailed section" in Supplementary information, Fig. 1) is transitional and terrestrial, and encompasses the $\mathrm{K}-\mathrm{Pg}$ boundary (López-Martínez et al., 2001, 2006, including a regional geological review). According to the scheme by Rosell et al. (2001), the continental levels start with the "Grey Garumnian" and the LRG unit deposited on top of the Arén Sandstone Formation (Fig. 1). The "detailed succession" is composed of greyish marls, sandstones and limestones plus $10 \mathrm{~m}$ of reddish mudstones and sandstones. The thick lacustrine-marine limestones on top of the section are the lateral equivalent of the Danian Salarons Formation (Eichenseer, 1987). López-Martínez et al. (2001, 2006) placed the boundary above a sandstone layer within the greyish marls containing marine fauna such as rudists and the ammonoid Pachydiscus gollevillensis. The $\mathrm{K}-\mathrm{Pg}$ boundary is located within an interval of a few metres between the level with Cretaceous fossils and the Danian Salarons Formation (see Supplementary information).

In order to better constrain the location of the $\mathrm{K}-\mathrm{Pg}$, a major part of the Campo section is here studied in magnetostratigraphic terms (Supplementary information). Additional information is also provided by rudist determinations and vertebrate footprints. Rudists occurring in the $\mathrm{K}-\mathrm{Pg}$ section in Campo (Supplementary information, Fig. 3) are well preserved (i.e. they did not undergo significant erosion) and belong to two different clades: Biradiolites ara Pons 1977, and Monopleuridae indet. Regarding vertebrate ichnites, we found isolated hadrosaur footprints preserved as casts at the base of limestones whose morphology is similar to that described in other sections of the Tremp Formation (Vila et al., 2013). Stratigraphically above this, in the reddish sandstones there are abundant tracks produced by buoyant crocodiles at the bottom of the channels as they swam. These resemble those described at the site of Serraduy Norte in similar stratigraphic levels (Vila, Castanera, Marmi, Canudo, \& Galobart, 2015). Moreover, the magnetostratigraphy indicates that this part of the section is in a reverse polarity magnetochron, unambiguously identified as C29r. Hence, the $\mathrm{K}-\mathrm{Pg}$ boundary is constrained within a reduced interval of $6 \mathrm{~m}$, between the last ammonoids, rudists and vertebrate tracks and the overlying Danian limestones. Recently, Burrel et al. (2014) have reported small-sized microspherules in the most modern part of the LRG unit at Campo, but to date the diagenetic alteration of these has prevented them from being proved to be microtektites.

\subsection{Serraduy-Rin section}

In the vicinity of Serraduy (Fig. 1) the Tremp Formation crops out with great lateral and horizontal continuity, making it easier to identify the different lithological sections of which it is composed. Vertebrate fossil remains are very abundant (Fig. 2), especially dinosaur remains in the upper part of the LRG unit (Company, Cruzado-Caballero, \& Canudo, 2015; Puértolas-Pascual et al., 2012; Vila et al., 2012), but crocodylomorphs are also well represented (Puértolas-Pascual et al., 2014; Vila et al., 2015). Hadrosauroid footprints are particularly abundant and can be identified in almost all the sandstone levels (Vila et al., 2013) that are stratigraphically above the last hadrosaurid bones found (Company et al., 2015). Fairly complete remains such as the holotype of the eusuchian crocodylomorph Allodaposuchus subjuniperus have been found immediately above the last sandstones of the LRG unit (Puértolas-Pascual et al., 2012, 2014). The Danian limestones found in Campo can be tracked to the Serraduy area (Arostegi, Baceta, Pujalte, \& Carracedo, 2011; Eichenseer, 1987), where they are thinner. No vertebrate remains have been found in the more modern clays of the LRG unit situated immediately beneath this limestone (Fig. 2). Hence, the location of the $\mathrm{K}-\mathrm{Pg}$ boundary can be constrained within an interval of $25 \mathrm{~m}$ between the last Cretaceous vertebrate remains and the Danian limestones, analogous lithologically to the Campo section.

\subsection{Iscles section}

This outcrop is situated to the east of the village of Serraduy (Fig. 1), but the Iscles and Serraduy outcrops do not show lateral continuity and are interrupted by Palaeogene conglomerates. However, the Iscles section correlates with the Blasi section, located 


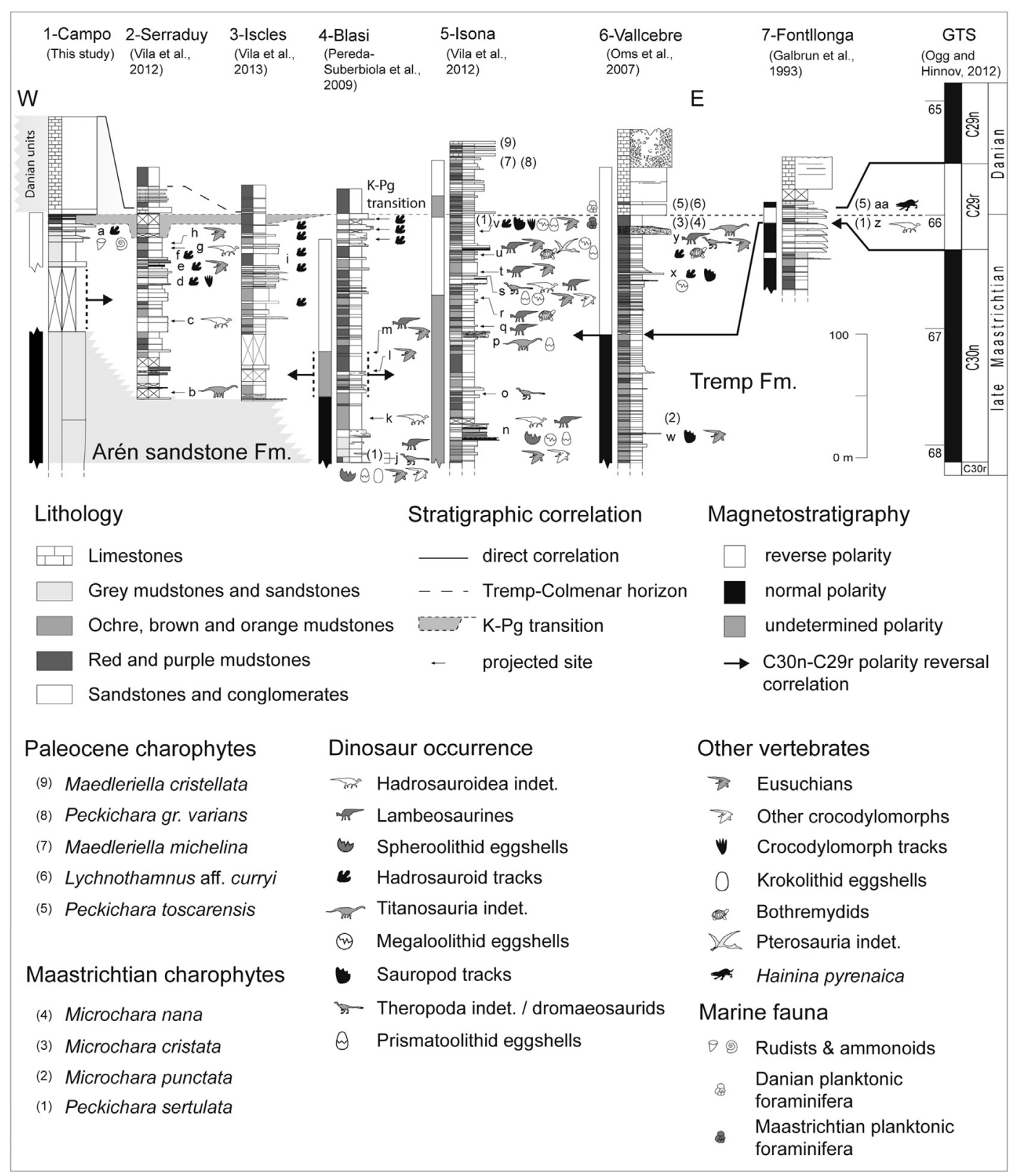

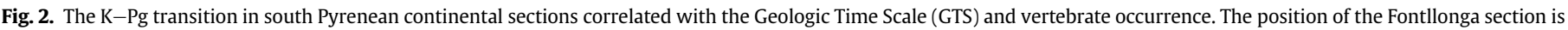

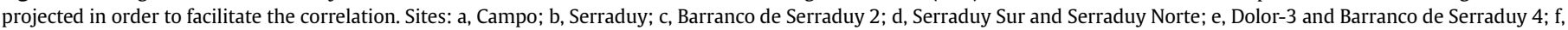

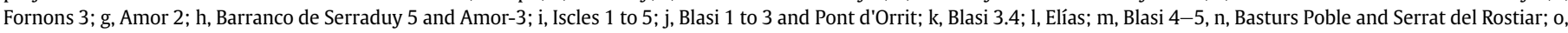

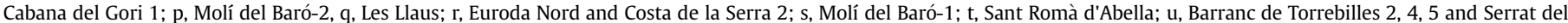

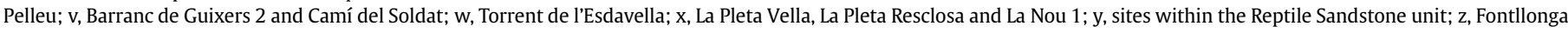

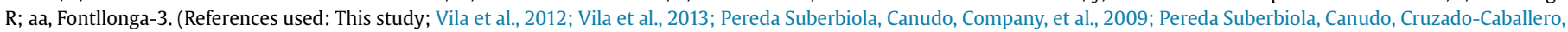
et al., 2009; Oms et al., 2007; Galbrun et al., 1993; Ogg \& Hinnov, 2012).

eastwards (see below). The channelled sandstones that form the LRG unit present hadrosauroid footprints that are threedimensionally preserved as natural casts (Vila et al., 2013), as well as fragmentary vertebrate remains amongst which possible hadrosauroids have been identified (Fig. 2). The footprints levels from the LRG unit have been correlated with C29r (Vila et al., 2013). In the Iscles section, a level of gypsum (with a thickness from 1 to $4 \mathrm{~m}$ ) is located $10 \mathrm{~m}$ above the last dinosaur remains. This layer can be correlated with the gypsum levels that overlie the abovementioned Danian limestones of Serraduy-Rin (Arostegi et al., 2011), or the Tremp-Colmenar horizon sensu Eichenseer (1987). If this correlation is correct, it implies that the $\mathrm{K}-\mathrm{Pg}$ boundary might be eroded or not recorded in this section. Above this gypsum level, there is a thick and very well exposed succession of the "Upper Red Garumnian" (red mudstones and sandstones) that is remarkably azoic in terms of vertebrate remains.

\subsection{Blasi section}

The Blasi section is located west of the village of Arén/Areny (Fig. 1), a few kilometres from the section of Iscles. The top of the Arén Sandstone Formation and the Tremp Formation are well exposed in the Blasi area. There are at least six fossiliferous levels (Fig. 2) with abundant hadrosaurid dinosaurs (Blasisaurus, 
Arenysaurus and tracks) and crocodylomorphs (Arenysuchus) located in the "Grey Garumnian" unit and the LRG unit (Barco, Ardèvol, \& Canudo, 2001; Cruzado-Caballero, Canudo, MorenoAzanza, \& Ruiz-Omeñaca, 2013, 2015; López-Martínez et al., 2001; Moreno-Azanza, Bauluz, Canudo, Puértolas-Pascual, \& Sellés, 2014; Pereda Suberbiola, Canudo, Company, et al., 2009; Pereda Suberbiola, Canudo, Cruzado-Caballero, et al., 2009; Puértolas, Canudo, \& Cruzado-Caballero, 2011). The age of the Blasi sites has been inferred using magnetostratigraphy (Pereda Suberbiola, Canudo, Cruzado-Caballero, et al., 2009). The fossiliferous sites Blasi 2 and 3 from the "Grey Garumnian" unit are located in a normal polarity magnetochron that has been correlated with C30n. The site Elías, where the holotype of Arenysuchus was collected, is located in an undetermined polarity interval between magnetochrons C30n and C29r. In addition, the sites Blasi 4 and 5 and the track levels from the LRG unit have been correlated with C29r (Cruzado-Caballero et al., 2014; Vila et al., 2013). Even though Danian limestones are missing in the Blasi section, they occur in the surrounding area. Accordingly, the $\mathrm{K}-\mathrm{Pg}$ boundary is constrained within an interval of less than $10 \mathrm{~m}$ between the last dinosaur footprints and these Danian limestones (Fig. 2).

\subsection{Isona sector}

One of the thickest exposures of the Tremp Formation (reaching some $400 \mathrm{~m}$ ) occurs in the area around the municipalities of Isona $\mathrm{i}$ Conca Dellà and Tremp. Here, the succession displays a transition from coastal to lagoonal and fluvial environments with marine influence. The LRG unit is mainly characterized by fine-grained point-bar deposits (meandering streams) interbedded with thick fine overbank deposits (floodplain) (Díez-Canseco et al., 2014; Riera et al., 2009; Vila et al., 2013). The Suterranya limestones overlie the LRG unit. The area has provided the richest vertebrate fossil record (dinosaur tracks, bones and egg-sites, but also crocodile, turtle and pterosaur remains, Fig. 2) in the whole Pyrenean area (CasanovasCladellas, Santafé-Llopis, \& Isidro-Llorens, 1993; Dalla Vecchia et al., 2013, 2014; López-Martinez et al., 1999; Marmi et al., 2012; Sellés, Vila, \& Galobart, 2014b; Vila et al., 2012). Recently, Vila et al. (2012) include a magnetostratigraphic study of data combined from several subsections, but overall the results are less conclusive than in the other areas. A reverse polarity interval found in the top metres of the composite section, below the Suterranya limestones, is interpreted there as C29r. Biostratigraphic studies have also been carried out using dinosaur eggshells (Sellés \& Vila, 2015), planktonic foraminifera (Díez-Canseco et al., 2014) and charophytes (Feist \& Colombo, 1983), though these are not resolute enough to constrain the $\mathrm{K}-\mathrm{Pg}$ boundary or transition. To make the scenario more complicated, the Suterranya limestones, which overlie the LRG unit and its last dinosaur remains, have been considered older than the Danian limestones of Campo, Serraduy-Rin and Vallcebre by some authors (Díez-Canseco et al., 2014; Krauss, 1991). These authors have thus suggested the existence of a sedimentary hiatus comprising the earliest Palaeocene, as is also observed in the Iscles section. This would imply that the K-Pg transition of this area does not record the boundary itself.

\section{6. Àger-Fontllonga section}

The Maastrichtian succession of the Àger Syncline near the locality of Fontllonga (Fig. 2) exhibits a transition from the marine Calcàries de les Serres Formation to the lacustrine and fluvial deposits of the Tremp Formation (López-Martínez et al., 1998). Whereas the "Grey Garumnian" in the Tremp Syncline is represented by lagoonal settings, in the Àger area it is represented by a thick succession $(50 \mathrm{~m}$ ) of lacustrine limestones (Villalba-Breva \&
Martín-Closas, 2012). There are also remarkable differences in the sandstone architecture of the LRG unit between the two synclines. In this respect, coarser sandstone bodies represent mainly braided streams in the fluvial settings of the Àger Syncline (Colombo \& Cuevas, 1993). Palaeomagnetic results from Galbrun, Feist, Colombo, Rocchia, and Tambareau (1993) placed the magnetochrons C30n-C29r transition within these fluvial deposits. The $\mathrm{K}-\mathrm{Pg}$ boundary was constrained within an interval of about $3 \mathrm{~m}$ within magnetochron C29r (Fig. 2) on the basis of the charophyte biostratigraphy, vertebrate occurrence and a significant reduction in the $\delta^{13} \mathrm{C}$ isotope values above the last dinosaur remains (LópezMartínez et al., 1998). This negative $\delta^{13} \mathrm{C}$ excursion has been used in marine and continental successions as a marker of the $\mathrm{K}-\mathrm{Pg}$ boundary, e.g. in nearby Provence (Cojan \& Moreau, 2006). In addition, Astibia, López-Martínez, Elorza, and Vicens (2012) suggested a link between the appearance of giant microbialites above the boundary in the area and the ecological disaster triggered by the $\mathrm{K}-\mathrm{Pg}$ event. In the upper levels of the Cretaceous part of the C29r magnetochron, a non-hadrosaurid hadrosauroid dentary has been recovered (Casanovas, Pereda-Suberbiola, Santafé, \& Weishampel, 1999; Pereda Suberbiola, Canudo, Company, et al., 2009), representing one of the youngest fossil records of this dinosaur group in the area (Fig. 2). There is only one site from the lower Palaeocene in the southern Pyrenees with crocodile remains, and these are indeterminate (López-Martínez, Álvarez-Sierra, Daams, Peláez-Campomanes, \& Sevilla, 1996, 1998). These authors recognized several vertebrates and plants including fishes, turtles, mammals, bird eggshells and crocodylomorphs at the site of Fontllonga 3, which they interpreted to be earliest Danian (top of magnetochron C29r).

\subsection{The Vallcebre composite section}

Similarly to the Tremp Syncline, the end-Cretaceous strata of the Vallcebre Syncline are represented by marine units that shift to thick lagoonal and continental deposits ("Grey Garumnian" unit and LRG unit respectively) during the Maastrichtian. A robust magnetostratigraphic scheme (Oms et al., 2007) has been established, displaying a continuous record from C32n to C29r (i.e. the entire Maastrichtian). An expanded C29r contains the "Reptile Sandstone", an extensive unit that represents proximal alluvial deposits. This yields the last dinosaur remains (Fig. 2), including hadrosauroids, titanosaurid sauropods and theropods as well as other vertebrates such as bothremydid turtles, eusuchian crocodylomorphs (Blanco, Méndez, et al., 2015; Pereda-Suberbiola, Ruiz-Omeñaca, Ullastre, \& Masriera, 2003; Sellés, Marmi, Llácer, \& Blanco, 2015) and hadrosaurid footprints (Vila et al., 2013). The $\mathrm{K}-\mathrm{Pg}$ boundary is constrained by charophyte biostratigraphy within an interval just a few metres thick right below the Vallcebre limestones (Vicente, Martín-Closas, Arz, \& Oms, 2015).

\section{The upper Maastrichtian archosaur record}

Archosaur fossil remains are notably abundant in the upper Maastrichtian sandstone levels of the Arén Sandstone Formation and the "Grey Garumnian" and "Lower Red Garumnian" units of the Tremp Formation. As a whole, these formations have provided 155 fossil sites in the southern Pyrenees and yielded more than 200 archosaur occurrences including skeletal remains (121 occurrences), eggs and eggshells (50 occurrences) and tracks (42 occurrences). The fossil record encompasses occasional bone beds, isolated carcasses, microvertebrate accumulations, track horizons and surfaces, isolated eggs, complete clutches and nesting horizons, etc. These are mostly found in fluvial, lacustrine and palustrine deposits (Riera et al., 2009). Remarkable sites are those of Els 
Nerets, Orcau 1, Basturs Poble, Blasi (1-5), Fontllonga R, Sant Romà d'Abella, Serraduy, Barranc de Torrebilles (1-5), Coll de Nargó and Basturs eggsites, Camí del Soldat, Cingles del Boixader, Iscles (1-5), Molí del Baró (1 and 2), among many others (Fig. 2; Blanco, PrietoMárquez, \& de Esteban-Trivigno, 2015; Dalla Vecchia et al., 2014; López-Martínez, 2003; Marmi et al., 2015; Riera et al., 2009; Sellés \& Vila, 2015). As a whole, five distinct groups make up the archosaur fossil record: hadrosauroid ornithopods, titanosaurid sauropods, theropods, indeterminate pterosaurs, and a diverse set of eusuchian crocodylomorphs. The dinosaurs present in the upper Maastrichtian were the result of an important faunal turnover (Le Loeuff, Buffetaut, \& Martin, 1994) that in the Vallcebre Syncline has been recently constrained around the $\mathrm{C} 31 \mathrm{r}-\mathrm{C} 31 \mathrm{n}$ reversal in the early late Maastrichtian (Vila et al., 2015).

\subsection{Hadrosauroidea}

Hadrosauroid dinosaur remains are particularly abundant (Fig. 2), with more than forty bone and track sites (Blanco, PrietoMárquez, et al., 2015; Cruzado-Caballero et al., 2014; Dalla Vecchia et al., 2014; López-Martínez et al., 2001; Prieto-Márquez et al., 2013; Vila et al., 2013). At least six different taxa are known together with many remains whose fragmentary condition has prevented any taxonomic assignment with confidence up to date (Blanco, Prieto-Márquez, et al., 2015; Casanovas et al., 1993; Company et al., 2015; Cruzado-Caballero et al., 2014; Pereda Suberbiola, Canudo, Company, et al., 2009; Pereda Suberbiola, Canudo, Cruzado-Caballero, et al., 2009; Prieto-Márquez et al., 2013). One lambeosaurine species, Blasisaurus canudoi (Cruzado-Caballero, Pereda-Suberbiola, et al., 2010; Cruzado-Caballero, Ruiz-Omeñaca, et al., 2010), is described from the uppermost levels of the Arén Sandstone Formation in the Arén area. In addition, two other lambeosaurine species have been described in the Tremp Formation. One of the species, Arenysaurus ardevoli (Cruzado-Caballero et al., 2013; Pereda Suberbiola, Canudo, Cruzado-Caballero, et al., 2009), corresponds to a single individual from the Blasi 3 level in the "Grey Garumnian" unit near the village of Arén (Fig. 1). Other, distinct dinosaur-bearing horizons from the "Grey Garumnian" unit and LRG unit in the area are referred to as Blasi 2 to 5 (CruzadoCaballero, Pereda-Suberbiola, et al., 2010; Cruzado-Caballero, Ruiz-Omeñaca, et al., 2010; 2014; López-Martínez et al., 2001; Pereda Suberbiola, Canudo, Cruzado-Caballero, et al., 2009). In the LRG unit the site of Sant Romà d'Abella near the homonymous village yielded the type material of the other lambeosaurine Pararhabdodon isonensis (Casanovas et al., 1993). Also in the LRG unit, an indeterminate lambeosaurine specimen was recovered from Les Serretes site near the village of Tremp (Blanco, Prieto-Márquez, et al., 2015). Moreover, other fragmentary specimens indicate the presence of at least three different non-hadrosaurid hadrosauroids from the uppermost levels of the LRG unit (the specimens from Fontllonga R, Barranc de la Costa Gran, Molí del Baró-1 and Blasi 3.4; Blanco, Prieto-Márquez, et al., 2015; Casanovas et al., 1999; Cruzado-Caballero et al., 2013; Pereda Suberbiola, Canudo, Cruzado-Caballero, et al., 2009), together with the striking discovery of diminutive hadrosauroids recently described in the Serraduy section (Company et al., 2015). Note that one of the former non-hadrosaurid hadrosauroid taxa, the remains of which were found in Barranc de la Costa Gran, Molí del Baró-1 and Basturs Poble, also consists of small-sized adult individuals (Blanco, PrietoMárquez, et al., 2015). More than 25 hadrosauroid tracks and occasional trackways are found in the upper horizons of the LRG unit. They are remarkably abundant in levels correlated with the Cretaceous part of C29r (Vila et al., 2013).

Tracks do not admit the possibility of reworking processes, as may occur in bone remains, so the autochthonous character of fossil tracks provides unmistakeable proof of the presence of hadrosauroids at the very end of the Maastrichtian in the southern Pyrenees. This is also supported by the presence of isolated bones attributed to hadrosaurids, some of them showing an affinity to lambeosaurines, in the Reptile Sandstone from the Vallcebre Syncline and neighbouring areas (Blanco, Méndez, et al., 2015; PeredaSuberbiola et al., 2003). Other localities in the Tremp Syncline included in C29r, such as Barranc de Torrebilles and Molí del Baró-1 have also yielded both cranial and postcranial remains of hadrosauroids including basal forms and derived lambeosaurines (Blanco, Prieto-Márquez, et al., 2015; Dalla Vecchia et al., 2014; Marmi et al., 2015). Recently, Sellés et al. (2014b) have described at the type locality (Porrit 6) in the LRG unit the new ootaxon Spheroolithus europaeus attributed to hadrosauroid dinosaurs, which is the first presence of this fossil egg type in the Upper Cretaceous of Europe and moreover the youngest evidence of it in Eurasia.

\subsection{Sauropoda}

The scarcity of sauropod fossil remains in the upper Maastrichtian has been interpreted as the consequence of their replacement by "hadrosaurs" at the end of the early Maastrichtian (Le Loeuff et al., 1994). However, new discoveries have indicated that sauropods were diverse even in the late Maastrichtian, ruling out a decline at the very end of the Cretaceous in the IberoArmorican island (Vila et al., 2012). The sauropods of the upper Maastrichtian are represented by bones, eggshells and tracks in the LRG unit (Fig. 2). At least four distinctive titanosaurid taxa (of small, medium and large size) have been recognized on the basis of bone material, two of the forms being found within the uppermost part of magnetochron C30n in the uppermost Maastrichtian of Molí del Baró-2 and Serraduy (Fig. 2; Vila et al., 2012). About forty megaloolithid egg and eggshell occurrences have been found in the upper Maastrichtian deposits of the southern Pyrenees (LópezMartínez, 2003; Vila, Galobart, et al., 2010; Sellés \& Vila, 2015; Vila, Jackson, et al., 2010; 2011 and references therein). This egg type is usually associated with titanosaurid sauropods (Chiappe, Salgado, \& Coria, 2001). Two oogenera are reported (Megaloolithus and Fusioolithus) in the upper Maastrichtian of the Pyrenean region, represented by two oospecies: Megaloolithus mamillare and Fusioolithus baghensis. The oospecies M. siruguei is also found in the basal upper Maastrichtian (last occurrence of dinosaurs near the C31r-C31n reversal; Vila et al., 2011), but it is more common in the "pre-turnover" assemblages, in the upper Campanian and the lower Maastrichtian deposits (Vila et al., 2015), and it is not considered here as typical of the upper Maastrichtian. Megaloolithus mamillare and $F$. baghensis have been reported in localities from the LRG unit and the top of the Arén Sandstone Formation (Sellés \& Vila, 2015 and references therein). La Nou1 site must be considered the youngest egg-site in the Pyrenees, which yields M. mamillare, and clearly falling within the C29r (Sellés \& Vila, 2015).

Sauropod footprints are scarce in the LRG unit (Fig. 2). LópezMartínez et al. (1998) described uncertain structures, which were considered sauropod footprints, but a recent review of the site ruled out this ascription due to their bad preservation (Martinell, Gibert, \& de Domenech, 2001; Vila et al., 2013). The latter authors described an unequivocal and isolated sauropod footprint from the Barranc de Guixers 2 site, in the upper part of the LRG unit, representing the youngest evidence of sauropods in the Pyrenean basins. A partial cervical vertebra of a titanosaurid sauropod has recently been reported in the Reptile Sandstone exposed at the El Portet locality, near the city of Berga (Sellés et al., 2015). This is the youngest bone remnant attributed to a titanosaurid found in the 
Tremp Formation. Previously, Ullastre and Masriera (1998) reported a probable sauropod dorsal vertebra was cited by in the same locality, but this specimen is currently lost.

\subsection{Theropoda}

Theropod remains are very scarce and fragmentary in the southern Pyrenees (Fig. 2). The theropod fossil record consists of isolated teeth, bones and eggshells (López-Martínez et al., 2001; Marmi et al., 2015; Prieto-Márquez et al., 2000; Riera et al., 2009; Sellés et al., 2014a; Torices et al., 2015). In the Tremp Formation the isolated shed teeth of theropods are present in microvertebrate sites or beside the carcasses of herbivorous dinosaurs (Marmi et al., 2015). To date, teeth have not been found in association with maxillary, dentary or postcranial remains demonstrably belonging to the same individual. The teeth are indicative of significant biodiversity, especially of small maniraptoran theropods. At least five different theropod taxa have been identified in the upper Maastrichtian, on the basis of dental morphology: Coelurosauria indet., cf. Dromaeosauridae indet., cf. Richardoestesia, cf. Euronychodon and an indeterminate, large-sized taxon with plesiomorphic teeth identified as Theropoda indet. or Neoceratosauria indet. (Torices et al., 2015). Among the very few theropod bone remains found in the Tremp Formation, it is important to note the discovery of a partial diaphysis of a probable small limb bone from the Reptile Sandstone cropping out near the city of Berga (Blanco, Méndez, et al., 2015). Two assemblages of theropod ootaxa dating from the upper Campanian to the upper Maastrichtian can be recognized in the southern Pyrenees (Sellés et al., 2014a). The transition between these assemblages occurred in the early Maastrichtian, when oospecies from both associations coexisted. The oodiversity is maximal during the late Campanian but decreases in the Maastrichtian. In the upper Maastrichtian only one oospecies (Prismatoolithus trempii) has been identified (Sellés et al., 2014b), its youngest record being found in the Camí del Soldat locality (Tremp basin), probably in C29r (Fig. 2).

\subsection{Crocodylomorpha}

The most significant remains from the upper Maastrichtian of the southern Pyrenees correspond to two new species of eusuchian crocodylomorphs described from cranial and postcranial material. These species are Allodaposuchus subjuniperus from Serraduy (Puértolas-Pascual et al., 2014), and Arenysuchus gascabadiolorum from Arén (Puértolas et al., 2011). Both these taxa belong to Allodaposuchidae, a clade composed of eusuchian crocodylomorphs that was very common in the Upper Cretaceous of Europe (Puértolas-Pascual, Blanco, Brochu, \& Canudo, 2015). Alternatively, however, the most recent hypothesis suggests that these taxa might be early representatives of the clade Crocodylia (Blanco et al., 2014). Furthermore, isolated remains, mostly teeth belonging to Crocodylomorpha, are abundant in the Tremp and Arén Sandstone Formations (Blanco, Bolet, et al., 2015; Buscalioni, Ortega, Weishampel, \& Jianu, 2001; Casanovas et al., 1987; LópezMartínez et al., 2001; Marmi et al., 2015; Puértolas-Pascual et al., 2015). These teeth have very similar morphologies to those presented by other crocodylomorphs from the Upper Cretaceous of Europe such as Allodaposuchus, Acynodon, Doratodon, Theriosuchus and Thoracosaurus.

Focuzing on the crocodylomorph record of the uppermost Cretaceous (C29r) in the southern Pyrenees (Fig. 2), several remains have been reported. In the Serraduy section (Huesca), two general morphotypes of isolated teeth have been distinguished. These teeth are very similar to those present in eusuchians such as Allodaposuchus and the marine taxon Thoracosaurus (Puértolas-Pascual et al., 2015). The most noticeable remnant from Serraduy is the complete skull of the eusuchian A. subjuniperus recovered from the LRG unit, within the uppermost sandstone strata (Amor 3 site) bearing vertebrate fossil remains, located $25 \mathrm{~m}$ below the Danian limestones. A. subjuniperus represents one of the youngest continental records of Crocodylomorpha from the Upper Cretaceous of Europe. In addition to fossil bones, several crocodylomorph tracks have been found at the site of Serraduy Norte (Vila et al., 2015), within levels equivalent to the site of Amor 3. In the youngest Cretaceous levels (the sites of Blasi 4 and 5) cropping out in the Arén area (Huesca), which are also located in the LRG unit, undetermined crocodylomorph remains and eusuchian osteoderms were collected previously (López-Martínez et al., 2001).

Other uppormost Cretaceous localities within magnetochron C29r yielding crocodylomorph remains are located in Catalonia. Most of the Catalan localities are found in the Tremp Syncline (Isona section, Fig. 2). Within this area, the sites of Molí del Baró 1, Camí del Soldat and Sant Romà d'Abella have yielded several isolated crocodylomorph teeth which have been related with taxa such as Allodaposuchus, ziphodont crocodylomorphs, Theriosuchus and other indeterminate crocodylomorphs (Blanco \& Bolet, 2014; Marmi et al., 2015; Puértolas-Pascual et al., 2015). As regards Molí del Baró-1, this site records a high diversity of crocodylomorph faunas. Recently, Marmi et al. (2015) have described ten morphotypes of crocodylomorph teeth from this locality. These morphotypes could represent at least seven, or possibly more, different taxa, including allodaposuchids, atoposaurids, and ziphodont and other indeterminate crocodylomorphs. However, this assumption should be taken with caution due to the limited diagnostic value of isolated teeth. Indirect fossil evidence has been found in Barranc de Guixers 2, where crocodylomorph tracks assigned to Characichnos have been described (Vila et al., 2015). In the Àger Syncline (Lleida), at the uppermost Maastrichtian site of La Mata del Viudà (C29r), crocodylomorph tracks assigned to the same ichnogenus were reported by the same authors. Near the Vallcebre Syncline (Barcelona), at the site of Cingles de la Creueta, an isolated tooth with conical generalist morphology similar to Allodaposuchus has recently been reported (Blanco, Bolet, et al., 2015). Within the Palaeogene there is only one site from the lower Palaeocene with indeterminate crocodylomoph fossil remains in the southern Pyrenees (López-Martínez et al., 1998). These authors recognized undetermined crocodylomorph remains at the site of Fontllonga-3 (earliest Danian, top of magnetochron C29r). These remains represent the first and only record of Crocodylomorpha in the earliest continental Palaeocene of Europe; unfortunately they have never been described or classified.

\subsection{Pterosauria}

The fossil record of flying reptiles is very scarce and incomplete in the southern Pyrenees (Fig. 2). Indeed, pterosaur remains have only been found in the Barranc de Torrebilles locality in the eastern Tremp Syncline (Isona). The remains are from the upper part of the LRG unit (C29r) and consist of fragmentary and poorly preserved limb bones referable to a large pterosaur of uncertain taxonomical affinity (Dalla Vecchia et al., 2013).

\section{Discussion}

For the last decades, the debate on the Cretaceous-Palaeogene extinction event has been focussed on how it occurred (geologically abrupt or gradual), and which were the timing and nature of the causes that produced it. The gradualist proposal stated that the terrestrial vertebrates -including dinosaurs- went extinct before the boundary in a stepwise extinction unlinked to the $\mathrm{K}-\mathrm{Pg}$ event. 
The catastrophist theory, by contrast, strictly posited an instantaneous extinction, without the occurrence of a prior degradation of ecosystems as a result of other factors such as volcanism (Fastovsky \& Sheehan, 2005). The current evidence indicates that the dinosaur extinction was abrupt in geological terms and suggests the Chicxulub impact as the most likely fundamental cause of the extinction, although the coarseness of the fossil record makes it difficult to test how Deccan volcanism may have affected dinosaurs during the final 400,000 years of the Cretaceous (Archibald et al., 2010; Brusatte et al., 2015). In recent years the debate around the Cretaceous-Palaeogene event has concentrated on whether the extinction was single- or multi-cause (Archibald et al., 2010). In this regard, some authors reported evidence for the temporal coincidence of multiple physical factors and hypothesized that the Chicxulub impact might have triggered most of the volcanic eruptions (Richards et al., 2015).

In the European context, the goal of the investigations being carried out in the southern Pyrenees is namely to document the evidence in the greatest possible detail: whether there was a reduction in diversity in the final few hundred thousand years of the Maastrichtian; and consequently, whether the extinction really was completely abrupt. The putative disappearance of the Pyrenean dinosaurs prior to the limit (Galbrun, 1997) constituted one of the main arguments supporting claims that the degradation of continental ecosystems several million years before the boundary was the cause of the extinction of dinosaurs; however, recent data indicate that dinosaur fossils - especially bones and footprints are abundant in the LRG unit (López-Martínez, 2003, Fig. 2), making it easy to find isolated remains or footprints at the base of the uppermost sandstone levels (Vila et al., 2013) very close to the alleged $\mathrm{K}-\mathrm{Pg}$ boundary.

The main problem in studying the extinction of dinosaurs in the Tremp Formation is the difficulty in pinpointing the boundary between the Cretaceous and the Palaeogene The period during which the dinosaurs disappeared is situated in the uppermost portion of the LRG unit, coinciding with the upper part of C30n and the lower part of C29r, and thus it should be located very close to, or coinciding with, the level that contains evidence of the $\mathrm{K}-\mathrm{Pg}$ meteorite impact. Ongoing work in the "Lower Red Garumnian" unit has not detected clear evidence of the meteorite impact in the Tremp Formation, such as microtektites or the iridium anomaly, but at least two sauropod taxa (form 4 and the Serraduy form) were present in the upper part of C30n, together with the sauropod tracks found in the Isona section (last occurrence of sauropods in magnetochron C29r), and bone remains from El Portet (Fig. 2, Blanco, Méndez, et al., 2015; Sellés et al., 2015; Vila et al., 2013). Hadrosauroids, especially hadrosaurids are particularly abundant and diverse in the LRG unit. This does not mean that the record of the six different taxa identified in this unit necessarily persists to the end of the Cretaceous, but at least two of the taxa, the small hadrosaurid from Serraduy (Company et al., 2015) and the enigmatic hadrosauroid from Fontllonga R (Casanovas et al., 1999), are located in the uppermost part of the LRG unit (Fig. 2), as well as the hadrosaurid remains from two sites in the Reptile Sandstone (Blanco, Méndez, et al., 2015). In addition, the strongest evidence that the group reached the end of the Maastrichtian is the ubiquitous tracks found the uppermost levels of magnetochron C29r (Fig. 2). At present, the record of theropod dinosaurs in the upper Maastrichtian is very fragmentary and consists mainly of isolated teeth. In the sites where an accumulation has been found, such as Blasi 2 from the “Grey Garumnian" unit (magnetochron C30n top) and Molí del Baró 1 from the LRG unit (magnetochron C29r), there is significant small-theropod diversity and at least one large form, yet their presence has not been unequivocally established in the upper part of the LRG unit either as bones or footprints (Blanco, Bolet, et al.,
2015). This absence is doubtless a matter of taphonomy and sampling. The tracks and bones of crocodylomorphs are present in magnetochron C29r, and some localities, such as Molí del Baró 1 (Marmi et al., 2015), suggest a notable diversity of these taxa, including atoposaurids, "ziphosuchians" and eusuchians. By contrast, evidence of pterosaurs is very poor in the uppermost Cretaceous of the Pyrenees, with the only known remains found in magnetochron C29r (Dalla Vecchia et al., 2013). No exceptional accumulation of vertebrate fossils has been found close to where the $\mathrm{K}-\mathrm{Pg}$ boundary might be located, but Cutler and Behrensmeyer (1996) showed that vertebrate mass accumulations are not expected at extinction horizons.

The Palaeogene part of magnetochron C29r and all the succession above is very poor in vertebrate remains, even though large and similar outcrops (red beds) are found, which are comparable with those from the Maastrichtian. The reason for this scarcity is beyond the scope of this paper, but a few considerations are discussed below. Relatively dry conditions would be the main reason, probably reducing biomass, biodiversity and the likelihood of preservation. This hypothesis is supported by three kinds of evidence. First, the marine influence indicators present in the LRG unit (Díez-Canseco et al., 2014) are not found in the "Upper Red Garumnian" unit, and some authors (see discussion in Rosell et al., 2001) even consider the latter unit to have formed in the dry conditions of a playa lake (with plenty of evaporites). Second, clay minerals (Arostegi et al., 2011) also indicate a climatic shift from temperate (perennial) subhumid conditions in the LRG unit to warm seasonal conditions in the "Upper Red Garumnian" unit. Third, stable isotopes at the Palaeocene site of Fontllonga-3 indicate a subtropical, seasonally dry climate (Domingo, López-Martínez, Soler-Gijón, \& Grimes, 2007), and comparable results were found by Riera, Anadón, Oms, Estrada, and Maestro (2013) in the Tremp Formation and in similar successions in Provence (southern France) by Cojan and Moreau (2006), who reported a change to semiarid conditions for the Danian. However, areas that preserve semiarid and subtropical climates can preserve terrestrial vertebrates perfectly, and this is not a sufficient argument for the absence of fossil vertebrates in the Danian of the southern Pyrenees. This could mean that the Danian terrestrial ecosystems of the southern Pyrenees took longer than other areas of the world to recover their biodiversity after the $\mathrm{K}-\mathrm{Pg}$ extinction event.

\section{Conclusions}

The southern Pyrenees contain a palaeontological record of vertebrates and especially of dinosaurs that is of great significance for understanding the changes and successions of biota in the last few thousand years of the Mesozoic and the beginning of the Palaeogene. For these reasons, this area can be considered one of the major geographical regions in the world for providing data on the extinction of the dinosaurs and their relationship to the boundary event.

On the basis of this fossil record, a well-dated succession of dinosaurs is established within C30 and C29r. Almost 150 sites with dinosaur remains have been identified, containing hadrosauroid ornithopods, titanosaurid sauropods and theropods, as well as egg sites and tracks. Fossil remains of dinosaurs and other archosaurs are abundant in magnetochron C29r, disappearing abruptly near the top of the "Lower Red Garumnian" unit of the Tremp Formation. Thus this should be located very close to, or coinciding with the $\mathrm{K}-\mathrm{Pg}$ boundary. This pattern has been recognized in the Vallcebre, Tremp and Àger Synclines. No remains of Mesozoic vertebrates have been found in the Vallcebre Limestone or its lateral equivalents (such as the Suterranya Limestone). This disappearance coincides with other preliminary evidence in the same stratigraphic 
interval, such as isotopic changes. So far, there is no incontrovertible evidence of the presence of the impact level that marks the Cretaceous-Palaeogene boundary. Isolated tracks and dinosaur bones have been found very close to where the boundary is thought to be.

Our research process is bringing to light the relation of the extinction of dinosaurs in the Pyrenees with the evidence of the impact that caused the $\mathrm{K}-\mathrm{Pg}$ boundary. The two events appear to be very close in time, but we cannot now show that they coincide with a resolution of a few hundred thousand years, given our current knowledge and the level of accuracy of the geological and palaeontological record. However, a more precise coincidence is necessary to determine whether the impact of the meteorite was the true cause of the extinction of the dinosaurs or whether it was brought about by other factors.

\section{Acknowledgements}

This paper is a tribute to Prof. Nieves López Martínez (deceased in 2010); some of the research included here was conducted under her guidance. This paper forms part of the projects CGL201453548-P, CGL2011-25581, CGL2011-30069-C02-01,02/BTE, subsidized by the Spanish Ministerio de Economía y Competitividad, the European Regional Development Fund, and the European Social Fund. Moreover, the Generalitat de Catalunya, the University of Zaragoza and the Government of Aragón, ("Grupos Consolidados" and "Dirección General de Patrimonio Cultural") funded the fieldwork. B. Vila acknowledges support from the Ministerio de Economía y Competitividad (Subprograma Juan de la Cierva MICINNJDC, 2011). E. Puértolas is supported by the program Formación del Profesorado Universitario (FPU) subsidized by the Spanish Ministerio de Educación, Cultura y Deportes. V. Fondevilla is supported by the program Formación del Personal Investigador (FPI, BES-2012-052366), subsidized by the Spanish Ministerio de Economía y Competitividad. A. Blanco is supported by a FI AGAUR grant from the DGR of the Generalitat de Catalunya (2013FI_B 01059). We thank David E. Fastovsky (Universität Wien) and Hugues Alexandre Blain (Institut de Paleoecologia Humana i Evolució Social) for their comments on the original manuscript during the peer-review process. Rupert Glasgow revised the English of the text.

\section{References}

Alvarez, L. W., Alvarez, W., Asaro, F., \& Michel, H. V. (1980). Extraterrestrial cause for the Cretaceous-Tertiary extinction. Science, 208, 1095-1108.

Archibald, J. D., Clemens, W. A., Padian, K., Rowe, T., MacLeod, N., Barrett, P. M., et al (2010). Cretaceous extinctions: multiple causes. Science, 328, 973.

Archibald, J. D., \& Fastovsky, D. E. (2004). Dinosaur extinction. In D. B. Weishampel, P. Dodson, \& H. Osmólska (Eds.), The Dinosauria (2nd ed., pp. 672-684). Berkeley: University of California Press.

Arostegi, J., Baceta, J. I., Pujalte, V., \& Carracedo, M. (2011). Late CretaceousPalaeocene mid-latitude climates: inferences from clay mineralogy of continental-coastal sequences (Tremp- Graus area, southern Pyrenees, N Spain). Clay Minerals, 46, 105-126.

Arz, J. A., Arenillas, I., \& Molina, E. (1999). Extinción de foraminíferos planctónicos en el tránsito Cretácico/Terciario de Zumaya (Guipúzcoa): ¿supervivencia o reelaboración? Revista Española de Micropaleontología, 31, 297-304.

Astibia, H., López-Martínez, N., Elorza, J., \& Vicens, E. (2012). Increasing size and abundance of microbialites (oncoids) in connection with the $\mathrm{K} / \mathrm{T}$ boundary in non-marine environments from the South-Central Pyrenees. Geologica Acta, 3, 209-226.

Baceta, J. I., Pujalte, V., Serra-Kiel, J., Robador, A., \& Orue-Etxebarria, X. (2004). El Maastrichtiense final, Paleoceno e Ilerdiense inferior de la Cordillera Pirenaica. In J. A. Vera (Ed.), Geología de España (pp. 308-313). Madrid: Sociedad Geológica de España - Instituto Geológico y Minero de España.

Barco, J. L., Ardèvol, L., \& Canudo, J. I. (2001). Descripción de los primeros rastros asignados a Hadrosauridae (Ornithopoda, Dinosaurio) del Maastrichtiense de la Península Ibérica (Arény, Huesca). Geogaceta, 30, 235-238.

Blain, H. A., Canudo, J. I., Cuenca-Bescós, G., \& López-Martínez, N. (2010). Amphibians and squamates from the latest Maastrichtian (Upper Cretaceous) of Blasi 2 (Huesca, Spain). Cretaceous Research, 31, 43-446.
Blanco, A., \& Bolet, A. (2014). Updating the knowledge on faunal assemblages from the Tremp Formation (late Cretaceous, upper Maastrichtian): microvertebrate remains from four new sites. In J. Marmi, O. Oms, B. Vila, À. Galobart, R. Estrada, \& J. Dinarès-Turell (Eds.), Reconstructing the Terrestrial End-Cretaceous Paleoenvironments in Europe (p. 60). Paleontologia i Evolució Special Issue 7.

Blanco, A., Bolet, A., Blain, H. A., Fondevilla, V., \& Marmi, J. (2015). Late Cretaceous (Maastrichtian) amphibians and squamates from northeastern Iberia. Cretaceous Research (this volume).

Blanco, A., Méndez, J. M., \& Marmi, J. (2015). The fossil record of the uppermost Maastrichtian Reptile Sandstone (Tremp Formation, northeastern Iberian Peninsula). Spanish Journal of Paleontology, 30 (this volume).

Blanco, A., Prieto-Márquez, A., \& de Esteban-Trivigno, S. (2015). Diversity of hadrosauroid dinosaurs from the Late Cretaceous Ibero-Armorican Island (European Archipelago) assessed from dentary morphology. Cretaceous Research (this volume).

Blanco, A., Puértolas-Pascual, E., Marmi, J., Vila, B., \& Sellés, A. G. (2014). Allodaposuchus palustris sp. nov. from the Upper Cretaceous of Fumanya (South-Eastern Pyrenees, Iberian Peninsula): systematics, palaeoecology and palaeobiogeography of the enigmatic allodaposuchian crocodylians. PloS ONE, 9, e115837.

Brusatte, S. L., Butler, R. J., Barrett, P. M., Carrano, M. T., Evans, D. C., Lloyd, G. T., et al. (2015). The extinction of the dinosaurs. Biological Reviews, 90, 628-642.

Burrel, L., Oms, O., Estrada, R., Vicens, E., Dinarès-Turell, J., Fondevilla, V., et al. (2014). Constraining the K-Pg boundary in the Campo section (Southern Pyrenees, Spain). In J. Marmi, O. Oms, B. Vila, À. Galobart, R. Estrada, \& J. DinarèsTurell (Eds.), Reconstructing the Terrestrial End-Cretaceous Paleoenvironments in Europe (p. 63). Paleontologia i Evolució Special Issue 7.

Buscalioni, A. D., Ortega, F., Weishampel, D. B., \& Jianu, C. M. (2001). A revision of the crocodyliform Allodaposuchus precedens from the Upper Cretaceous of the Hateg Basin, Romania. Its relevance in the phylogeny of Eusuchia. Journal of Vertebrate Paleontology, 21, 74-86.

Canudo, J. I. (1997). El Kef Blind test I results. Marine Micropaleontology, 29, 73-77.

Casanovas-Cladellas, M. L., Santafé-Llopis, J. V., \& Isidro-Llorens, A. (1993). Pararhabododon isonense n. gen. n.sp. (Dinosauria). Estudio morfológico, radiotomográfico y consideraciones biomecánicas. Paleontologia i Evolució, 26-27, $121-131$.

Casanovas, M. L., Pereda-Suberbiola, X., Santafé, J. V., \& Weishampel, D. B. (1999). A primitive euhadrosaurian dinosaur from the uppermost Cretaceous of the Ager syncline (southern Pyrenees, Catalonia). Geologie en Mijnbouw, 78, 345-356.

Casanovas, M. L., Santafé, J. L. Sanz, J. L., \& Buscalioni, A. D. (1987). Arcosaurios (Crocodilia, dinosauria) del Cretácico Superior de la Conca de Tremp (Lleida, España). Estudios Geológicos, Volumen Extra Galve-Tremp, 95-110.

Chiappe, L. M., Salgado, L., \& Coria, R. A. (2001). Embryonic skulls of titanosaur sauropod dinosaurs. Science, 293, 2444-2446.

Clemens, W. A., \& Hartman, J. H. (2014). From Tyrannosaurus rex to asteroid impact: early studies (1901-1980) of the Hell Creek Formation in its type area. The Geological Society of America Special Paper, 503, 1-87.

Cojan, I., \& Moreau, M. G. (2006). Correlation of terrestrial climatic fluctuations with global signals during the upper Cretaceous/Danian in a compressive setting (Provence, France). Journal of Sedimentary Research, 76, 589-604.

Colombo, F. (1996). Stratigraphic and sedimentary characteristics of the CretaceousTertiary boundary in the Ager basin, Lleida province, Spain. In N. MacLeod, \& G. Keller (Eds.), Cretaceous-tertiary mass extinctions. Biotic and environmental changes (pp. 399-413). New York: W.W. Norton and C.

Colombo, F., \& Cuevas, J. L. (1993). Características estratigráficas y sedimentológicas del "Garumniense" en el sector de Ager (Pre-Pirineo, Lleida). Acta Geologica Hispánica, 28, 15-32.

Company, J., Cruzado-Caballero, P., \& Canudo, J. I. (2015). Presence of diminutive hadrosaurids (Dinosauria: Ornithopoda) from the Maastrichtian of the southcentral Pyrenees (Spain). Journal of Iberian Geology, 41, 71-81.

Courtillot, V. E., Feraud, G., Maluski, H., Vandamme, D., Moreau, M. G. \& Besse, J (1988). Deccan flood basalts and the Cretaceous/Tertiary boundary. Nature, 333, 843-846.

Cruzado-Caballero, P., Canudo, J. I., Moreno-Azanza, M., \& Ruiz-Omeñaca, J. I. (2013) Arenysaurus ardevoli, a lambeosaurine dinosaur from the Latest Maastrichtian of Arén (North Spain). Journal of Vertebrate Paleontology, 33, 1367-1384.

Cruzado-Caballero, P., Fortuny, J., Llacer, S., \& Canudo, J. I. (2015). Paleoneuroanatomy of the european lambeosaurine dinosaur Arenysaurus ardevoli. PeerJ, 3, e802.

Cruzado-Caballero, P., Pereda-Suberbiola, X., \& Ruiz-Omeñaca, J. I. (2010). Blasisaurus canudoi gen. et sp. nov., a new lambeosaurine dinosaur (Hadrosauridae) from the Latest Cretaceous of Arén (Huesca, Spain). Canadian Journal of Earth Sciences, 47, 1507-1517.

Cruzado-Caballero, P., Ruiz-Omeñaca, J. I., \& Canudo, J. I. (2010). Evidencias de la coexistencia de hadrosaurinos y lambeosaurinos en el Maastrichtiano superior de la Península Ibérica (Arén, Huesca, España). Ameghiniana, 47, 153-164.

Cruzado-Caballero, P., Ruiz-Omeñaca, J. I., Gaete, R., Riera, V., Oms, O., \& Canudo, J. I. (2014). A new hadrosaurid dentary from the latest Maastrichtian of the Pyrenees (north Spain) and the high diversity of the duck-billed dinosaurs of the Ibero-Armorican Realm at the very end of the Cretaceous. Historical Biology, 26, 619-630.

Cuevas, J. L. (1992). Estratigrafía del "Garumniense" de la Conca de Tremp. Prepirineo de Lérida. Acta Geológica Hispánica, 27, 95-108.

Cutler, A. H., \& Behrensmeyer, A. K. (1996). Models of vertebrate mass mortality 
events at the K/T Boundary. In G. Ryder, D. Fastovsky, \& S. Gartner (Eds.), The Cretaceous-tertiary event and other Catastrophes in Earth History (pp. 375-380). GSA Special Paper 307.

Dalla Vecchia, F. M., Gaete, R., Riera, V., Oms, O., Prieto-Márquez, A., Vila, B., et al. (2014). The hadrosauroid record in the Maastrichtian of the eastern Tremp Syncline (northern Spain). In D. Eberth, \& D. C. Evans (Eds.), Hadrosaurs: Proceedings of the International Hadrosaur Symposium at the Royal Tyrrell Museum (pp. 298-312). Bloomington: Indiana University Press.

Dalla Vecchia, F. M., Riera, V., Oms, O., Dinarès-Turell, J., Gaete, R., \& Galobart, À. (2013). The last pterosaurs: first record from the uppermost Maastrichtian of the Tremp Syncline (Northern Spain). Acta Geologica Sinica, 87, 1198-1227.

Dercourt, J., Gaetani, M., Vrielvynck, B., Barrier, E., Biju-Duval, B., Brunet, M. F., et al. (Eds.). (2000). Atlas Peri-Tethys Palaeogeographical (p. 269). Paris: Commission for the Geological Map of the World, 24 maps, explanatory notes I-XX.

Díaz-Molina, M., Kalin, O., Benito, M. I., López-Martínez, N., \& Vicens, E. (2007). Depositional setting and early diagenesis of the dinosaur eggshell-bearing Arén Fm at Bastus, Late Campanian, south-central Pyrenees. Sedimentary Geology, 199, 205-221.

Díez-Canseco, D., Arz, J. A., Benito, M. I., Díaz-Molina, M., \& Arenillas, I. (2014). Tidal influence in red beds: a palaeoenvironmental and biochronostratigraphic reconstruction of the Lower Tremp Formation (South-Central Pyrenees, Spain) around the Cretaceous/Paleogene boundary. Sedimentary Geology, 312, 31-49.

Dinarès-Turell, J., Westerhold, T., Pujalte, V., Röhl, U., \& Kroon, D. (2014). Astronomical calibration of the Danian stage (Early Paleocene) revisited: Settling chronologies of sedimentary records across the Atlantic and Pacific Oceans. Earth and Planetary Science Letters, 405, 119-131.

Domingo, L., López-Martínez, N., Soler-Gijón, R., \& Grimes, S. T. (2007). A multiproxy geochemical investigation of the early Paleocene (Danian) continental palaeoclimate at the Fontllonga-3 site (South Central Pyrenees, Spain). Palaeogeography, Palaeoclimatology, Palaeoecology, 256, 71-85.

Eichenseer, H. (1987). Facies Geology of Late Maestrichtian to Early Eocene Coastal and Shallow Marine Sediments, Tremp-Graus Basin, Northeastern Spain. Ph.D. Thesis (p. 237). Germany: University of Tübingen.

Fassett, J. E., Zielinski, R. A., \& Budahn, J. R. (2002). Dinosaurs that did not die: Evidence for Paleocene dinosaurs in the Ojo Alamo Sandstone, San Juan Basin, New Mexico (pp. 307-335). Geological Society of America. Special Paper 356.

Fastovsky, D. E., \& Sheehan, P. M. (2005). The extinction of the dinosaurs in North America. GSA Today, 15, 4-10.

Feist, M., \& Colombo, F. (1983). La limite Crétacé-Tertiaire dans le nord-est de l'Espagne, du point de vue des charophytes. Géologie Méditerranéenne, 10, 303-326.

Fernández-Marrón, M. T., López-Martínez, N., Fonollá-Ocete, J. F., \& ValleHernández, M. F. (2004). The Palynological Record across the Cretaceous-tertiary Boundary in two different Palaeogeographic settings from the Southern Pyrenees (Spain) (pp. 243-255). Geological Society of London. Special Publication 230.

Galbrun, B. (1997). Did the European dinosaurs disappear before the K-T event? Magnetostratigraphic evidence. Earth and Planetary Science Letters, 148, 569-579.

Galbrun, B., Feist, M., Colombo, F., Rocchia, R., \& Tambareau, Y. (1993). Magnetostratigraphy of Cretaceous-Tertiary continental deposits, Àger Basin, Province of Lérida, Spain. Palaeogeography, Palaeoclimatology, Palaeoecology, 102, 41-52.

Gallala, N., Zaghbib-Turki, D., Arenillas, I., Arz, J. A., \& Molina, E. (2009). Catastrophic mass extinction and assemblage evolution in planktic foraminifera across the Cretaceous/Paleogene (K/Pg) boundary at Bidart (SW France). Marine Micropaleontology, 72, 196-209.

Gómez-Gras, D., Roigé, M., Fondevilla, V., Oms, O., Boya, S., \& Remacha, E. (2015). Provenance constraints on the paleogeographical reconstruction of the Tremp formation in the South Pyrenean basin: Ebro massif vs. Pyrenees source area. Cretaceous Research (this volume).

Krauss, S. (1991). Stratigraphy and Facies of the "Garumnian"-Late Cretaceous to Early Paleogene-in the Tremp Region, Central Southern Pyrenees. Ph.D. thesis (p. 152). Germany: University of Tübingen.

Le Loeuff, J. (2012). Paleobiogeography and biodiversity of late Maastrichtian dinosaurs: how many dinosaur species went extinct at the Cretaceous-Tertiary boundary? Bulletin Société Géologique de France, 183, 547-559.

Le Loeuff, J., Buffetaut, E., \& Martin, M. (1994). The last stages of dinosaur faunal history in Europe: a succession of Maastrichtian dinosaur assemblages from the Corbières (southern France). Geological Magazine, 31, 625-630.

Li, L., \& Keller, G. (1998). Abrupt deep-sea warming at the end of the Cretaceous. Geology, 26, 995-998.

Llompart, C. (1979). Yacimiento de huellas de pisadas de reptil en el Cretácico superior prepirenaico. Acta Geológica Hispánica, 14, 333-336.

López-Martínez, N. (2003). La extinción de los dinosaurios y su registro en los Pirineos. In Colectivo Arqueológico-Paleontológico Salense (Ed.), Actas II Jornadas Internacionales sobre Paleontología de Dinosaurios y su Entorno (p. 71). Salas de los Infantes, Burgos.

López-Martínez, N., Álvarez-Sierra, A. M., Daams, R., Peláez-Campomanes, P., \& Sevilla, P. (1996). Vertebrate succesion from late Cretaceous to early Tertiary, South Central Pyrenees (Lleida, Spain). In J. E. Repetski (Ed.), Sixth North American Paleontological Convention; Abstracts of Papers (p. 246). Special Publication - The Paleontological Society 8.

López-Martínez, N., Ardèvol, L., Arribas, M. E., Civis, J., \& González-Delgado, A. (1998). The geological record in non-marine environments around the K/T boundary (Tremp Formation, Spain). Bulletin Société Géologique de France, 169, $11-20$.
López-Martínez, N., Arribas, M. E., Robador, A., Vicens, E., \& Ardèvol, L. (2006). Los Carbonatos Danienses (Unidad 3) de la Fm. Tremp (Pirineos Sur-Centrales): paleogeografía y relación con el límite Cretácico-Terciario. Revista de la Sociedad Geológica de España, 19, 233-255.

López-Martínez, N., Canudo, J. I., Ardévol, L., Pereda-Suberbiola, X., OrueEtxebarría, X., Cuenca-Bescós, G., et al. (2001). New dinosaur sites correlated with Upper Maastrichtian pelagic deposits in the Spanish Pyrenees: implications for the dinosaur extinction pattern in Europe. Cretaceous Research, 22, $41-61$.

López-Martínez, N., Fernández-Marrón, M. T., \& Valle, M. F. (1999). The succession of vertebrates and plants across the Cretaceous-Tertiary boundary in the Tremp Formation, Ager valley (South-central Pyrenees, Spain). Geobios, 32, 617-627.

MacLeod, N., Rawson, P. F., Forey, P. L., Banner, F. T., Boudagher-Facel, M. K., Bown, P. R., et al. (1997). The Cretaceous-Tertiary biotic transition. Journal of the Geological Society, 154, 265-292.

Marmi, J., Blanco, A., Fondevilla, V., Dalla Vecchia, F. M., Sellés, A. G., Vicente, A., et al. (2015). The Molí del Baró-1 site, a diverse fossil assemblage from the uppermost Maastrichtian of the southern Pyrenees (north-eastern Iberia). Cretaceous Research (this volume).

Marmi, J., Luján, À. H., Riera, V., Gaete, R., Oms, O., \& Galobart, À. (2012). The youngest species of Polysternon: a new bothremydid turtle from the uppermost Maastrichtian of the southern Pyrenees. Cretaceous Research, 35, 133-142.

Martinell, J., Gibert, J. M., \& de Domenech, R. (2001). Cretaceous ray traces? An alternative interpretation for the alleged dinosaur tracks of La Posa, Isona, NE Spain. Palaios, 16, 409-416.

Masriera, A., \& Ullastre, J. (1983). Essai de synthèse stratigraphique des couches continentales de la fin du Crétacé des Pyrénées Catalanes (NE de l'Espagne). Géologie Méditerranéenne, 10, 283-290.

Médus, J., Feist, M., Rocchia, R., Batten, D. J., Boclet, D., Colombo, F., et al. (1988). Prospects for recognition of the palynological Cretaceous/Tertiary boundary and an iridium anomaly in nonmarine facies of the eastern Spanish Pyrenees: a preliminary report. Newsletters on Stratigraphy, 18, 123-138.

Mey, P. H. W., Nagtegaal, P. J. C., Roberti, K. J. A., \& Hartelvelt, J. J. A. (1968). Lithostratigraphic sub-division of posthercynian deposits in the south central Pyrenees, Spain. Leidse Geologische Mededelingen, 41, 221-228.

Miller, K. G., Kominz, M. A., Browning, J. V., Wright, J. D., Mountain, G. S., Katz, M. E., et al. (2005). The phanerozoic record of global sea-level change. Science, 310, 1293-1298.

Molina, E., Alegret, L., Arenillas, I., Arz, J. A., Gallala, N., Hardenbol, J., et al. (2006) The Global Boundary Stratotype Section and Point for the base of the Danian Stage (Paleocene, Paleogene, "Tertiary", Cenozoic) at El Kef, Tunisia: original definition and revision. Episodes, 29, 263-273.

Molina, E., Angori, E., Arenillas, I., Brinkhuis, H., Crouch, E. M., Luterbacher, H., et al. (2003). Correlation between the Paleocene/Eocene boundary and the Ilerdian at Campo, Spain. Revue de Micropaléontologie, 46, 95-109.

Molina, E., Arenillas, I., \& Arz, J. A. (1998). Mass extinction in planktic foraminifera at the Cretaceous/Tertiary boundary in subtropical and temperate latitudes. Bulletin de la Société Géologique de France, 169, 351-363.

Moreno-Azanza, M., Bauluz, B., Canudo, J. I., Puértolas-Pascual, E., \& Sellés, A. G. A. (2014). A re-evaluation of aff. Megaloolithidae eggshell fragments from the uppermost Cretaceous of the Pyrenees and implications for crocodilomorph eggshell structure. Historical Biology, 26, 195-205.

Muñoz, J. A. (1989). The structure of the Pyrenees. In M. Marzo, \& C. Puigdefábregas (Eds.), Alluvial Deposits of the Successive Foreland Basin Stages and Their Relation to the Pyrenean Thrust Sequences, 4th International Conference on Fluvial Sedimentology (pp. 7-13). Barcelona: Servei Geològic de Catalunya. Guidebook series, Excursion num. 10.

Ogg, J. G., \& Hinnov, L. A. (2012). Cretaceous. In F. M. Gradstein, \& J. G. Ogg (Eds.), The geologic time scale 2012 (Vol. 2, pp. 793-853). Elsevier.

Oms, O., Dinarès-Turell, J., Vicens, E., Estrada, R., Vila, B., Galobart, À., et al. (2007) Integrated stratigraphy from the Vallcebre Basin (southeastern Pyrenees, Spain); new insights on the continental Cretaceous-Tertiary transition in southwest Europe. Palaeogeography, Palaeoclimatology, Palaeoecology, 255, 35-47.

Oms, O., Fondevilla, V., Riera, V., Marmi, J., Vicens, E., Estrada, R., et al. (2015). Transitional environments of the Maastrichtian south Pyrenean basin (Catalonia, Spain): the Fumanya Member tidal flat. Cretaceous Research (this volume).

Oms, O., Pérez-Cano, J., Fondevilla, V., Anadón, P., Ibáñez, J., Rejas, M., et al. (2014) On the search of the $\mathrm{K}-\mathrm{Pg}$ Boundary in the terrestrial record in Europe: Preliminary. Geochemical data from the Puig Pedrós section (Tremp Basin, catalonia, Spain). In Abstract Book Reconstructing the terrestrial end-Cretaceous Paleoenvironments in Europe (Tremp, 2014) (p. 74). Paleontologia i Evolució, Special Issue 7.

Payros, A., Pujalte, V., Baceta, J. I., Bernaola, G., Orue-Etxebarria, X., Apellaniz, E., et al. (2000). Lithostratigraphy and sequence stratigraphy of the upper Thanetian to middle Ilerdian strata of the Campo section (southern Pyrenees, Spain): revision and new data. Revista de la Sociedad Geológica de España, 13 213-226.

Pereda-Suberbiola, X., Canudo, J. I., Company, J., Cruzado-Caballero, P., \& RuizOmeñaca, J. I. (2009). Hadrosaurids from the latest Cretaceous of the Iberian Peninsula: new interpretations. Journal of Vertebrate Paleontology, 29, 946-951.

Pereda Suberbiola, X., Canudo, J. I., Cruzado-Caballero, P., Barco, J. L., LópezMartínez, N., Oms, O., et al. (2009). The last hadrosaurid dinosaurs of Europe: a new lambeosaurine from the uppermost Cretaceous of Arén (Huesca, Spain). 
Comptes Rendus Palevol, 8, 559-572.

Pereda-Suberbiola, X., Ruiz-Omeñaca, J. I., Ullastre, J., \& Masriera, A. (2003). Primera cita de un dinosaurio hadrosaurio en el Cretácico Superior del Prepirineo oriental (Peguera, provincia de Barcelona). Geogaceta, 34, 195-198.

Philip, J., \& Floquet, M. (2000). Late Maatrichtian (69.5 to 65 Ma). In J. Dercourt, M. Gaetani, B. Vrielynck, E. Barrier, B. Biju-Duval, M. F. Brunet, et al. (Eds.), Atlas Peri-Tethys, Palaeogeographical Maps (pp. 179-196). Paris: Commission of the Geologic Map of the World.

Prieto-Márquez, A., Dalla Vecchia, F. M. Gaete, R. \& Galobart, A. (2013). Diversity, relationships, and biogeography of the Lambeosaurine dinosaurs from the European archipielago, with description of the new Aralosurin Canardia garonnensis. PloS ONE, 8, e69835.

Prieto-Márquez, A., Gaete, R., Galobart, À., \& Ardévol, L. (2000). A Richardoestesialike theropod tooth from the Late Cretaceous foredeep, south-central Pyrenees, Spain. Eclogae geologica Helvetiae, 93, 497-501.

Puértolas-Pascual, E, Blanco, A. Brochu, C, \& Canudo, J. I, (2015). Review of the Late Cretaceous-Early Paleogene crocodylomorphs of Europe: extinction patterns across the K/Pg boundary. Cretaceous Research (this volume).

Puértolas-Pascual, E., Canudo, J. I., \& Moreno-Azanza, M. (2014). The eusuchian crocodylomorph Allodaposuchus subjuniperus sp. nov., a new species from the latest Cretaceous (upper Maastrichtian) of Spain. Historical Biology, 26, 91-104.

Puértolas-Pascual, E., Cruzado-Caballero, P., Canudo, J. I., Gasca, J. M., MorenoAzanza, M. Castanera, D. et al. (2012). Nuevos yacimientos de vertebrados de Maastrichtiense superior (Cretácico Superior) de Huesca (España). Geo-Temas (this volume).

Puértolas, E., Canudo, J. I., \& Cruzado-Caballero, P. (2011). A new crocodylian from the Late Maastrichtian of Spain: Implications for the initial radiation of crocodyloids. PloS ONE, 6, e20011.

Puigdefábregas, C., Muñoz, J. A., \& Marzo, M. (1986). Thrust belt development in the eastern Pyrenees and related depositional sequences in the southern foreland basin. In P. A. Allen, \& P. Homewood (Eds.), Foreland basins (pp. 229-246). Oxford: Blackwell.

Pujalte, V., \& Schmitz, B. (2005). Revisión de la estratigrafía del Grupo Tremp. (Garumniense, Cuenca de Tremp-Graus, Pirineos meridionales). Geogaceta, 38 $79-82$.

Renne, P. R., Deino, A. L., Hilgen, F. J., Kuiper, K. F., Mark, D. F., Mitchell, W. S., et al (2013). Time scales of critical events around the Cretaceous-Paleogene boundary. Science, 339, 684-687.

Richards, M. A., Alvarez, W., Stephen Self, S., Karlstrom, L., Renne, P. R., Manga, M. et al. (2015). Triggering of the largest Deccan eruptions by the Chicxulub impact. Geological Society of America Bulletin. http://dx.doi.org/10.1130/B31167.1.

Riera, V., Anadón, P., Oms, O., Estrada, R., \& Maestro, E. (2013). Dinosaur eggshell isotope geochemistry as tools of paleoenvironmental reconstruction for the upper Cretaceous from the Tremp Formation (Southern Pyrenees). Sedimentary Geology, 294, 356-370.

Riera, V., Oms, O., Gaete, R., \& Galobart, À. (2009). The end-Cretaceous dinosaur succession in Europe: the Tremp Basin record (Spain). Palaeogeography, Palaeoclimatology, Palaeoecology, 283, 160-171.

Rosell, J., Linares, R., \& Llompart, C. (2001). El “Garumniense” prepirenaico. Revista de la Sociedad Geológica de España, 14, 47-56.

Schulte, P. Alegret, L., Arenillas, A., Arz, J. A., Barton, P. J., Bown, P. R., et al. (2010). The Chicxulub asteroid impact and mass extinction at the CretaceousPaleogene boundary. Science, 327, 1214-1218.

Sellés, A. G., Marmi, J., Llácer, S., \& Blanco, A. (2015). The youngest sauropod evidence in Europe. Historical Biology (this volume).

Sellés, A. G., \& Vila, B. (2015). Re-evaluation of the age of some dinosaur localities from the southern Pyrenees by means of megaloolithid oospecies. Journal of Iberian Geology, 41, 125-139.

Sellés, A. G., Vila, B., \& Galobart, À. (2014a). Diversity of theropod ootaxa and its implications for the latest Cretaceous dinosaur turnover in southwestern Europe. Cretaceous Research, 49, 45-54.

Sellés, A. G., Vila, B., \& Galobart, À. (2014b). Spheroolithus europaeus, oosp. nov. (Late Maastricthtian, Catalonia), the youngest oological record of hadrosauroids in Eurasia. Journal of Vertebrate Paleontology, 34, 725-729.

Smit, J., \& Hertogen, J. (1980). An extraterrestrial event at the Cretaceous-Tertiary boundary. Nature, 285, 198-200.

Teixell, A. (2004). Estructura de los Pirineos: generalidades. In J. A. Vera (Ed.), Geología de España (pp. 321-323). Madrid: SGE-IGME.

Tobin, T. S., Ward, P. D., Steig, E. J., Olivero, E. B., Hilburn, I. A., Mitchell, R. N., et al (2012). Extinction patterns, $\delta^{18} \mathrm{O}$ trends, and magnetostratigraphy from a southern high-latitude Cretaceous-Paleogene section: links with Deccan volcanism. Palaeogeography, Palaeoclimatology, Palaeoecology, 350-352, $180-188$.

Torices, A., Currie, P., Canudo, J. I., \& Pereda Suberbiola, X. (2015). Theropod dinosaurs from the Upper Cretaceous of the South Pyrenean Zone. Acta Paleontologica Polonica, 60(3).

Ullastre, J., \& Masriera, A. (1998). Nuevas aportaciones al conocimiento estratigráfico del Paleoceno continental del Pirineo catalán (España). Treballs del Museu de Geologia de Barcelona, 7, 95-128.

Vicente, A., Martín-Closas, C., Arz, J. A., \& Oms, O. (2015). Maastrichtian-basal Paleocene charophyte biozonation and its calibration to the Global Polarity Time Scale in the southern Pyrenees (Catalonia, Spain). Cretaceous Research, 52, 268-285.

Vila, B., Castanera, D., Marmi, J., Canudo, J. I., \& Galobart, À. (2015). Crocodile swim tracks from the latest Cretaceous of Europe. Lethaia, 48, 256-263.

Vila, B., Galobart, À., Canudo, J. I., Le Loeuff, J., Dinarés-Turell, J., Riera, V., et al. (2012). The diversity of sauropod dinosaurs in the latest Cretaceous of Southwest of Europe. Palaeogeography, Palaeoclimatology, Palaeoecology, 350, 19-38.

Vila, B., Galobart, A., Oms, O., Poza, B., \& Bravo, A. M. (2010). Assessing the nesting strategies of Late Cretaceous titanosaurs: 3-D clutch geometry from a new megaloolithid eggsite. Lethaia, 43, 197-208.

Vila, B., Jackson, F. D., Fortuny, J., Sellés, A. G., \& Galobart, À. (2010). 3-D Modelling of megaloolithid clutches: insights about nest construction and dinosaur behaviour. PloS ONE, 5, e10362.

Vila, B., Oms, O., Fondevilla, V., Gaete, R., Galobart, À., Riera, V., et al. (2013). The latest succession of dinosaur tracksites in Europe: hadrosaur ichnology, track production and palaeoenvironments. PloS ONE, 8, e72579.

Vila, B., Riera, V., Bravo, A., Oms, O., Vicens, E., Estrada, R., et al. (2011). The chronology of dinosaur oospecies in south-western Europe: refinements from the Maastrichtian succession from the eastern Pyrenees. Cretaceous Research, 32, $378-386$.

Villalba-Breva, S., Marmi, J., Gomez, B., Daviero-Gomez, V., Martín-Closas, C., \& Fernández-Marrón, M. T. (2015). Plant taphonomy and palaeoenvironment from the Upper Cretaceous of Isona, Tremp Basin, southern Pyrenees, Catalonia, Spain. Cretaceous Research, 54, 34-49.

Villalba-Breva, S., \& Martín-Closas, C. (2012). Upper Cretaceous paleogeography of the Central Southern Pyrenean Basins (Catalonia, Spain) from microfacies analysis and charophyte biostratigraphy. Facies, 59, 319-345.

Villalba-Breva, S., Martín-Closas, C., Marmi, J., Gomez, B., \& Fernández-Marrón, M. T. (2012). Peat-forming plants in the Maastrichtian coals of the Eastern Pyrenees. Geologica Acta, 10, 189-207.

\section{Appendix A. Supplementary data}

Supplementary data related to this article can be found at http://dx.doi.org/10. 1016/j.cretres.2015.06.013. 